HSTC Bulletin

Journal of the History of Canadian Science, Technology and Medecine

hstc

Revue d'histoire des sciences, des techniques et de la médecine au Canada

bulletin

\title{
Kingston Conference
}

Volume 2, numéro 4 (8), august 1978

URI : https://id.erudit.org/iderudit/1082226ar

DOI : https://doi.org/10.7202/1082226ar

Aller au sommaire du numéro

Éditeur(s)

HSTC Publications

ISSN

0228-0086 (imprimé)

1918-7742 (numérique)

Découvrir la revue

Citer ce document

(1978). Kingston Conference. HSTC Bulletin, 2(4), 2-3.

https://doi.org/10.7202/1082226ar

All Rights Reserved (c) Canadian Science and Technology Historical Association / Ce document est protégé par la loi sur le droit d'auteur. L’utilisation des Association pour l'histoire de la science et de la technologie au Canada, 1978 services d'Érudit (y compris la reproduction) est assujettie à sa politique d'utilisation que vous pouvez consulter en ligne.

https://apropos.erudit.org/fr/usagers/politique-dutilisation/

Cet article est diffusé et préservé par Érudit.

Érudit est un consortium interuniversitaire sans but lucratif composé de l'Université de Montréal, l'Université Laval et l'Université du Québec à

Montréal. Il a pour mission la promotion et la valorisation de la recherche.

https://www.erudit.org/fr/ 
HSTC Bulletin is published quarterly by HSTC Publications, Downsview, ont.

Editors/Redacteurs: R.A. Jarrell (York University), N.R. Ball (Public Archives of Canada)

Iegal Deposit: National Library of Canada

Editorial Offic/Bureau de Redaction

HSTC Bulletin

c/o Dept. Natural Science

Atkinson College, York University

Downsview, Ontario. M3J 2R7

(416) $667-3271$

\section{KTNGSTON CONEERENCE}

Dr. A.W. Tickner (NRC) has announced the tentative schedule of events for the Conference on the Study of Canadian Science and Technology, to be held at the Queen's University, Kingston, Ontario, on 3-5 November 1978.

\section{Friday, 3 Novenber}

T.H. Ievere (Toronto)--"What is Canadian about the History of Canadian Science and Technology?"

Raymond Duchesne (Montréal) - "Problères d'histoire des sciences au Canada français"

\section{Saturday, 4 Noventber}

Panel on the Historical Profession:

A. Forster (HSSRC) on support

Ian Montagnes (Un. Tor. Press) on publication

Panel on Archival Resources:

Peter Gillis (PAC) on sources for water pollution in 19th century Canada

Jacques Bernier (Laval) on 'L'histoire de la médecine au Québec'

Arthur Ray (York) on Hudson's Bay Co. Archives

Workshops (parallel morning and afternoon sessions):

1. Archives: Sandra Guillaume (Ont. Multicultural Archives)

2. Medicine: T. Gelfand (Ottawa) , G.R. Paterson and M. Dunn

(Hannah Found.), J. Scott (Toronto), C.J. Roland (McMaster)

3. Museology: Crristopher Porter (Upper Canada Village)

4. Teaching Materials: George Richardson (Queen's)

5. Course Organization and Content: Richard Jarrell (York)

6. Invention and Discovery: Ioris Russel (ROM)

7. Adaptation and Innovation: James Petersen (Toronto)

8. Institutional Frameworks: J.W. Grove (Queen's)

Evening address by Dr. J.W.T. Spinks, President Emeritus of the University of Saskatchewan and physicist 
Sunday, 5 Novenber

Plenary Session: Rapporteurs' accounts of the workshops; discussion and resolutions

As spaces are limited at the conferenoe site (Donald Gordon Centre), those interested should contact Dr. Tickner at:

\author{
National Research Council, \\ Ottawa, Ontario \\ KIA OR6 \\ (613) 993-0286
}

\title{
SOURCES IN THE HISTORY OF CANADIAN ENGINEERING
}

The Engineering Institute of Canada Collection, which is now open for use at the Public Archives of Canada, should help solve one of the major problems in researching the history of engineering in Canada, namely the scarcity of accessible basic biographical and professional information.

Formed in 1887 as the Canadian Society of Civil Engineers, the EIC is Canada's first and oldest professional engineering society. At 150 linear feet (45 metres) the collection is quite large but the finding aid prepared by the author of this note makes it quite usable but not idiot-proof. The first 126 feet consists of alphabeticallyarranged.membership files. Applications for membership were submitted to referees and in many cases give considerable biographical and professional information. This generally includes date and place of birth, details of education, apprenticeships and other training, jobs and level of responsibility. In some cases there are references to publications or papers given. Often the date of death has been noted with perhaps the inclusion of an obituary. The finding aid indicates the alphabetical range for each box but does not give a list of every engineer. One must look in the partic ular box to see if the engineer in question is there. Researchers are reminded that because the collection is not stored in the main building it must be requested on weekdays only and it will take approximately half a day to retrieve material. Once in the main building it can be consulted twentyfour hours a day, seven days a week.

The remainder of the collection consists of material such as minutes of meetings, some correspondence, scrapbooks, membership lists, employment registers, periodical lists and other similar material.

It is hoped that during the next few years collection of other professional societies, both scientific and engineering, will be added to the holdings of the Public Archives of Canada. However, Continued on page 7 